\title{
In the Supreme Court of the annited States
}

\author{
BOARD OF TRUSTEES OF THE LELAND STANFORD \\ JUNIOR UNIVERSITY, PETITIONER
}

$v$.

Roche Molecular Systems, InC., ET AL.

ON PETITION FOR A WRIT OF CERTIORARI

TO THE UNITED STATES COURT OF APPEALS

FOR THE FEDERAL CIRCUIT

BRIEF FOR THE UNITED STATES AS AMICUS CURIAE

NEAL KUMAR KATYAL Acting Solicitor General Counsel of Record

TONY WEST

Assistant Attorney General

Malcolm L. StewarT

Deputy Solicitor General

BETH S. BRINKMANN

Deputy Assistant Attorney General

NiCOLE A. SAHARSKY

Assistant to the Solicitor General

SCOTT R. MCINTOSH

Teal Luthy Miller

Attorneys

Department of Justice

Washington, D.C. 20530-0001

SupremeCtBriefs@usdoj.gov (202) $514-2217$ 


\section{QUESTION PRESENTED}

The University and Small Business Patent Procedures Act of 1980, 35 U.S.C. 200 et seq., commonly known as the Bayh-Dole Act, establishes a framework for determining ownership interests in federally funded inventions. Under the Act, college and university, nonprofit, and small business federal contractors may "elect to retain title" to any invention conceived or reduced to practice in the performance of federally funded research. 35 U.S.C. 202(a). "If [the] contractor does not elect to retain title" to such an invention, the federal government may grant the inventor rights in the invention. 35 U.S.C. 202(d). The question presented is as follows:

Whether an inventor who is employed by a contractor that elects to retain rights in an invention may defeat the contractor's right to retain title under the BayhDole Act by contractually assigning his putative rights in the invention to a third party. 


\section{TABLE OF CONTENTS}

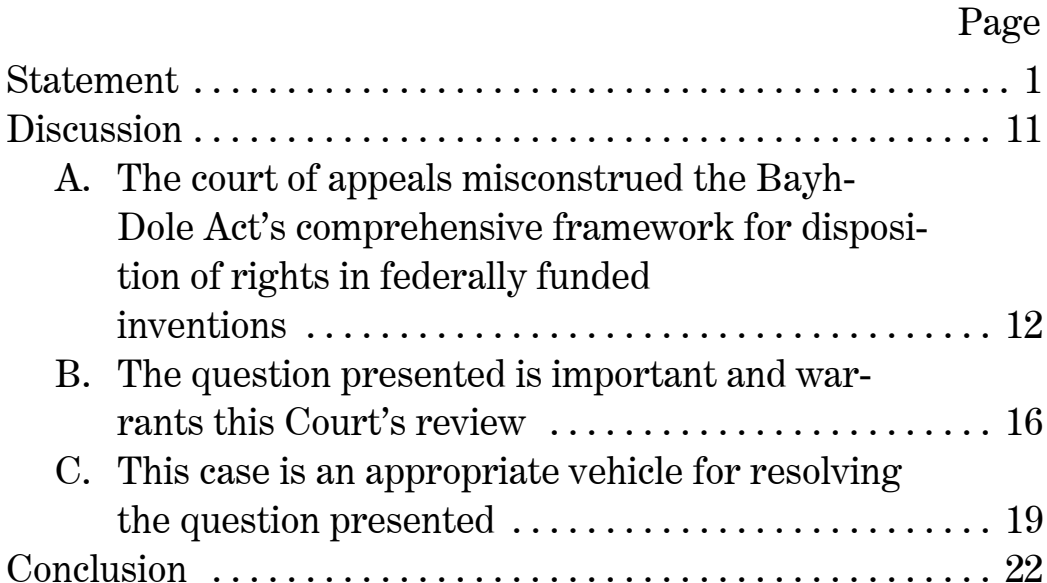

\section{TABLE OF AUTHORITIES}

Cases:

Arachnid, Inc. v. Merit Indus., Inc., 939 F.2d 1574

(Fed. Cir. 1991) .......................... 2

Board of Trs. of Leland Stanford Jr. Univ. v. Roche

Molecular Sys., Inc., 563 F. Supp. 2d 1016

(N.D. Cal. 2008) ........................ 9

Campbell Plastics Eng'g \& Mfg., Inc. v. Brownlee, 389 F.3d 1243 (Fed. Cir. 2004) . . . . . . . . . . . . . . 20

Central Admixture Pharmacy Servs., Inc. v. Advanced Cardiac Solutions, P.C., 482 F.3d 1347

(Fed. Cir.), cert. denied, 552 U.S. 1038 (2007) . . . . 15, 20

Festo Corp. v. Shoketsu Kinzoku Kogyo Kabushiki Co., 535 U.S. 722 (2002) ................... 19

Fidelity Fed. Bank \& Trust v. Kehoe, 547 U.S. 1051

(2006) ................................. 19

FilmTec Corp. v. Hydranautics, 982 F.2d 1546 (Fed.

Cir. 1992), cert. denied, 510 U.S. 824 (1993) ........ 2 
Cases-Continued: Page

Hudson v. Michigan, 547 U.S. 586 (2006) ...........20 20

Platzer v. Sloan-Kettering Inst. for Cancer Research, 787 F. Supp. 360 (S.D.N.Y. 1992) ............... 13

Statutes and regulation:

University and Small Business Patent Procedures Act, 35 U.S.C. 200 et seq. . ................. 2, 16 35 U.S.C. $200 \ldots \ldots \ldots \ldots \ldots \ldots \ldots \ldots \ldots \ldots$

35 U.S.C. $201(b) \ldots \ldots \ldots \ldots \ldots \ldots \ldots \ldots \ldots \ldots$

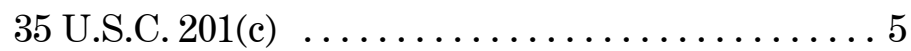

35 U.S.C. 201(e) ....................... 4

35 U.S.C. $202 \ldots \ldots \ldots \ldots \ldots \ldots \ldots \ldots \ldots \ldots . \ldots \ldots$

35 U.S.C. 202(a) ................ 5, 11, 12, 13

35 U.S.C. 202(a)(i)-(iv) ................... 6

35 U.S.C. $202(\mathrm{c})(1) \ldots \ldots \ldots \ldots \ldots \ldots \ldots \ldots, 13$

35 U.S.C. $202(\mathrm{c})(2) \ldots \ldots \ldots \ldots \ldots \ldots \ldots \ldots, 13$

35 U.S.C. 202(c)(3) $\ldots \ldots \ldots \ldots \ldots \ldots \ldots \ldots \ldots$

35 U.S.C. $202(\mathrm{c})(4) \ldots \ldots \ldots \ldots \ldots \ldots \ldots \ldots, 13$

35 U.S.C. $202(\mathrm{c})(7)(\mathrm{B}) \quad \ldots \ldots \ldots \ldots \ldots \ldots \ldots, 14$

35 U.S.C. $202(\mathrm{c})(7)(\mathrm{C}) \quad \ldots \ldots \ldots \ldots \ldots \ldots \ldots, 17$

35 U.S.C. $202(\mathrm{~d}) \ldots \ldots \ldots \ldots \ldots \ldots \ldots, 6,9,11,13$

35 U.S.C. $203 \ldots \ldots \ldots \ldots \ldots \ldots \ldots \ldots \ldots, 13,18$

35 U.S.C. $204 \ldots \ldots \ldots \ldots \ldots \ldots \ldots \ldots \ldots, 6,18$

35 U.S.C. 210 (a) $\ldots \ldots \ldots \ldots \ldots \ldots \ldots \ldots, 6,16$

28 U.S.C. 1295 ............................. 20

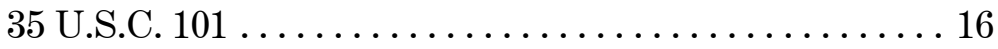

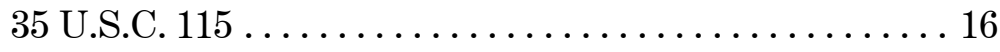


Statutes and regulation-Continued: Page

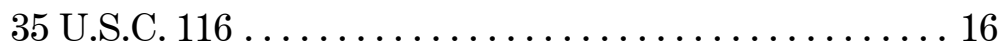

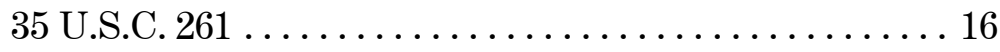

42 U.S.C. 1871(a) (1976) .................... 3

42 U.S.C. $2182(1976) \ldots \ldots \ldots \ldots \ldots \ldots \ldots \ldots \ldots \ldots$

42 U.S.C. 2457 (a) (1976) $\ldots \ldots \ldots \ldots \ldots \ldots \ldots \ldots \ldots$

42 U.S.C. $5908($ a) (1976) .................... 2

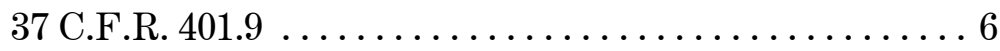

Miscellaneous:

126 Cong. Rec. 8739 (1980) _.................. 3

The Bayh-Dole Act-The Next 25 Years: Hearing

Before the Subcomm. on Technology and Innovation of the H. Comm. on Science and Technology, 110th Cong., 1st Sess. (2007) . . . . . . . . . . . 17

Federal Council for Science and Technology, Report on Government Patent Policy (1976) ........... 3, 4

Donna Fossum et al., Innovation in Academe: Federal R\&D Funding and the Patenting Activities of U.S. Universities and Colleges (2009) . . . 18, 19

Gov't Accountability Office, GAO-09-742, Information on the Government's Right to Assert Ownership Control Over Federally Funded Inventions (2009) .......................... 18, 3

Government Patent Policy Act of 1980: Hearings on H.R. 5715 Before the Subcomm. on Science, Research, and Technology of the H. Comm. on Science and Technology, 96th Cong., 2d Sess. (1980) ............................. 4

Eugene Gressman et al., Supreme Court Practice (9th ed. 2007) ..................... 19 
Miscellaneous-Continued:

H.R. Rep. No. 1307, 96th Cong., 2d Sess. Pt. 1 (1980) .................. 2, 3, 12, 16, 17

David C. Mowery et al., Ivory Tower and Industrial Innovation: University-Industry Technology Transfer Before and After the Bayh-Dole Act (2004) ............................... 3

National Science Foundation, NSF 10-311, Academic R\&D Expenditures: FY 2008 (2010) . . . . . . . 18 S. Rep. No. 480, 96th Cong., 1st Sess. (1979) ......... 3 


\title{
In the Supreme Court of the fanited States
}

\author{
No. 09-1159 \\ BOARD OF TRUSTEES OF THE LELAND STANFORD \\ JUNIOR UNIVERSITY, PETITIONER
}

$v$.

Roche Molecular Systems, InC., ET AL.

ON PETITION FOR A WRIT OF CERTIORARI

TO THE UNITED STATES COURT OF APPEALS

FOR THE FEDERAL CIRCUIT

\section{BRIEF FOR THE UNITED STATES AS AMICUS CURIAE}

This brief is submitted in response to this Court's invitation to the Solicitor General to express the views of the United States. In the view of the United States, the petition for a writ of certiorari should be granted.

\section{STATEMENT}

1. The United States has long supported technological research and innovation through funding grants to colleges and universities, nonprofit organizations, and small businesses. That support is substantial: more than half of the scientific and technical research conducted at colleges and universities in the United States is funded by federal grants. See Gov't Accountability Office, GAO-09-742, Information on the Government's Right to Assert Ownership Control Over Federally Funded Inventions 1 (2009) (GAO Report). 
Since 1980, the ownership of inventions arising out of federally funded research has been governed by the University and Small Business Patent Procedures Act of 1980, 35 U.S.C. 200 et seq., commonly known as the Bayh-Dole Act. Because the balance of interests struck in the Act is best understood in light of the history of ownership of federally funded inventions, this brief first describes that history and then describes the specific provisions of the Act at issue here.

2. Before 1980, no uniform source of law governed ownership of inventions that resulted from federally funded research. Instead, a "melange of 26 different agency policies" governed title to such inventions. H.R. Rep. No. 1307, 96th Cong., 2d Sess. Pt. 1, at 3 (1980) (House Report). For some agencies, statutes provided that title to patents on such inventions automatically vested in the federal government unless the agency waived its rights. See, e.g., 42 U.S.C. 2182, 5908(a) (1976) (Department of Energy); 42 U.S.C. 2457(a) (1976) (National Aeronautics and Space Administration). Those vesting statutes superseded an inventor's common law rights in his invention and his statutory patent rights. See Arachnid, Inc. v. Merit Indus., Inc., 939 F.2d 1574, 1578 (Fed. Cir. 1991) (describing inventor's common law and statutory rights). An inventor working on a federally funded project subject to those statutes therefore was not free to assign rights in his invention to third parties. Such an inventor had "no right to assign" because title to his invention "automatically vested in the United States" by “operation of law." FilmTec Corp. v. Hydranautics, 982 F.2d 1546, 1550, 1553 (Fed. Cir. 1992), cert. denied, 510 U.S. 824 (1993).

In contrast to agencies operating under vesting statutes, other agencies addressed ownership of patents for federally funded inventions by entering into agreements 
with individual research institutions. The National Science Foundation (NSF) and the Department of Health, Education and Welfare (HEW), for example, operated under Institutional Patent Agreement (IPA) programs adopted in the 1960s and 1970s. See David C. Mowery et al., Ivory Tower and Industrial Innovation: University-Industry Technology Transfer Before and After the Bayh-Dole Act 45 (2004). IPAs gave universities with established technology-transfer programs a first option to own federally funded inventions. See S. Rep. No. 480, 96th Cong., 1st Sess. 21 (1979). The university's right was subject to a number of conditions, including a requirement to report the invention to the government, grant the government a royalty-free license, refrain from charging excessive royalties to other licensees, use royalty income for the support of education or research, refrain from assigning rights except in limited circumstances, and take effective steps to commercialize the inventions. See, e.g., Federal Council for Science and Technology, Report on Government Patent Policy 330-339 (HEW IPA), 340-353 (NSF IPA) (1976) (Patent Policy Report).

Both the vesting statutes and the IPA programs had their shortcomings. Under the vesting statutes, the government often lacked the resources to develop and commercialize patent rights obtained through federally funded research. GAO Report 2; House Report 1-2. As a result, only about five percent of federally funded inventions were being marketed commercially. See 126 Cong. Rec. 8739 (1980) (statement of Sen. Dole); GAO Report 2. IPAs had a different but equally significant deficiency. The statutes governing several agencies, such as the NSF, prohibited the agencies from entering into contracts "inconsistent with any provision of law affecting the issuance or use of patents." 42 U.S.C. 1871(a) (1976). As a result, IPAs could not 
allocate ownership rights in federally funded inventions by their own force; such allocations were possible only if the university obtained an assignment of rights from the researcher. See Patent Policy Report 330 (HEW IPA), 342 (NSF IPA). An institution's failure to obtain an effective assignment of rights from the researcher thus could compromise the allocation of rights and obligations under the IPA. See, e.g., Government Patent Policy Act of 1980: Hearing on H.R. 5115 Before the Subcomm. on Science, Research, and Technology of the H. Comm. on Science and Technology, 96th Cong., 2d Sess. 80 (1980).

3. To address those shortcomings, Congress enacted the Bayh-Dole Act in 1980. The Act establishes a uniform framework for the disposition of rights in federally funded inventions. That framework was designed to "use the patent system to promote the utilization of inventions arising from federally supported research or development," while "ensur[ing] that the Government obtains sufficient rights in federally supported inventions to meet the needs of the Government and protect the public against nonuse or unreasonable use of inventions." 35 U.S.C. 200. Congress sought to balance the interests of the contracting institution, the government, and the inventor in a manner that would best "promote collaboration between commercial concerns and nonprofit organizations, including universities," and that would encourage "future research and discovery." Ibid.

The Act prescribes title to certain federally funded inventions, which are called "subject invention[s]." A "subject invention" is "any invention *** conceived or first actually reduced to practice in the performance of work under a funding agreement" between a contractor and a federal agency. 35 U.S.C. 201(e). A "contractor" is a "person, small business firm, or nonprofit organization that is a 
party to a funding agreement." 35 U.S.C. 201(c). The term "funding agreement" is broadly defined as "any contract, grant, or cooperative agreement entered into between any Federal agency, other than the Tennessee Valley Authority, and any contractor for the performance of experimental, developmental, or research work funded in whole or in part by the Federal Government." 35 U.S.C. 201(b).

The Act creates a presumption that title to federally funded inventions will vest in the contractor, rather than in the government or inventor. The section of the Act titled "Disposition of rights" provides that a contractor may "elect to retain title to any subject invention." 35 U.S.C. 202(a). To do so, the contractor must "disclose each subject invention to the Federal agency within a reasonable time after it becomes known to contractor personnel responsible for the administration of patent matters." 35 U.S.C. 202(c)(1). The government "may receive title to any subject invention not disclosed to it within such time." Ibid.

The contractor's title in a federally funded invention, however, is subject to certain conditions. In addition to a requirement that the contractor report subject inventions to the federal agency, see 35 U.S.C. 202(c)(1), the Act requires the contractor to "make a written election within two years after disclosure to the Federal agency (or such additional time as may be approved by the Federal agency)" specifying whether it will retain title to the invention, 35 U.S.C. 202(c)(2). If the contractor is a nonprofit organization, it must "share royalties with the inventor," 35 U.S.C. 202(c)(7)(B), and must utilize the royalties or income remaining to further "scientific research or education,” 35 U.S.C. 202(a), (c)(7)(B) and (C). The contractor must also ensure that any assignee that is granted the "exclusive right to use or sell any subject invention" agrees that any products made using the subject invention will be 
"manufactured substantially in the United States" unless the government waives that condition. 35 U.S.C. 204.

The government is entitled to an irrevocable, paid-up license from the contractor to practice a federally funded invention. 35 U.S.C. 202(c)(4). The government may keep title or otherwise restrict a contractor's title when particularly sensitive governmental interests are at stake, such as when a contractor is controlled by a foreign government or the research relates to foreign intelligence, nuclear propulsion, or nuclear weapons programs. 35 U.S.C. 202(a)(i)-(iv). The government also retains "march-in" rights to subject inventions, meaning that it may step in to license the invention in certain circumstances, such as when a contractor fails to take steps to achieve practical application of the invention, or when public health or safety requires it. 35 U.S.C. 203.

If a contractor does not elect to retain title to a subject invention, the government may decide whether to take title for itself or allow title to pass to the inventor. In such circumstances, the federal agency "may consider" - "and after consultation with the contractor grant"- "requests for retention of rights by the inventor." 35 U.S.C. 202(d). The inventor's rights remain "subject to the provisions of this Act and regulations promulgated hereunder." Ibid.; see 37 C.F.R. 401.9. Thus, the inventor may receive title to the invention only when the contractor chooses not to retain title (or fails to comply with the applicable statutory prerequisites) and the government affirmatively authorizes the inventor to take title.

The Bayh-Dole Act "take[s] precedence over any other Act which would require a disposition of rights in subject inventions of small business firms or nonprofit organizations contractors in a manner that is inconsistent with" the disposition of rights in the Act. 35 U.S.C. 210(a). Thus, 
unlike the pre-1980 experience with IPAs, when agencies like the NSF were required to conform their funding agreements to the Patent Act's allocation of rights, the BayhDole Act explicitly gives precedence to the Act's own "[d]isposition of rights." 35 U.S.C. 202.

4. This case concerns the ownership of three patents for monitoring the effectiveness of treatments for human immunodeficiency virus (HIV). The patented process was developed by researchers at the Leland Stanford Junior University (Stanford) using federal funds. One of those scientists-Dr. Mark Holodniy-performed research both at Stanford and at Cetus Corporation (Cetus). Holodniy executed agreements with both Stanford and Cetus regarding rights in his inventions, and a dispute subsequently arose about the ownership of the patents at issue here.

In the early to mid-1980s, Cetus developed polymerase chain reaction (PCR) technology, a technique for making billions of copies of specific sequences of DNA from a small number of starting molecules. Pet. App. 32a. In 1988, Cetus and Stanford began collaborating on the use of PCR in HIV/AIDS research. Ibid. That year, Holodniy began conducting research at Stanford's Center for AIDS Research. Ibid. Holodniy signed a "Copyright and Patent Agreement" with Stanford, $i d$. at 118a-121a, in which he "agree[d] to assign or confirm in writing to Stanford *** that right, title and interest in $* * *$ such inventions," $i d$. at 118a-119a.

In February 1989, Holodniy began making regular visits to Cetus to learn about PCR and to develop a PCRbased test for HIV. Pet. App. 4a. At Cetus, Holodniy signed a "Visitor's Confidentiality Agreement," $i d$. at 35a36a, in which he "assign[ed] to CETUS [his] right, title, and interest in" any inventions conceived or reduced to practice "as a consequence of [his] access to CETUS' facilities or 
information," id. at 123a. Holodniy's research with Cetus produced an assay (procedure) for using PCR to measure the amount of HIV nucleic acids in blood samples from people infected with HIV. Id. at 5a, 37a. Holodniy published these findings with Cetus co-authors. Ibid.

Holodniy then returned to Stanford and worked with others on clinical studies to determine whether the assay could be used to judge the efficacy of anti-HIV drugs. Pet. App. 5a, 39a. That research demonstrated that PCR can be used to track the HIV RNA in a patient's bloodstream to assess the effectiveness of anti-HIV drugs the patient is taking. Ibid. Holodniy published this discovery with several Stanford and Cetus co-authors. Id. at 38a-39a. The research underlying the discovery was funded in part by the federal government through an agreement with Stanford. Id. at 5a, 109a, 114a-115a.

In 1992, Stanford submitted a patent application for this method of monitoring the effectiveness of anti-HIV treatment, which resulted in the issuance of the three patents at issue. Pet. App. 108a-109a. Holodniy and two other scientists are named as co-inventors of these patents, and Stanford is identified as their assignee. Id. at 4a, 125a, 127a, 129a. Stanford disclosed the invention to the federal government, specifying that the "invention was made with Government support" and that "[t]he Government has certain rights in th[e] invention," and it confirmed to the government the grant of an irrevocable, paid-up license to the invention. Id. at 5a-6a. In 1995, Stanford formally elected to retain title to the invention under the Bayh-Dole Act. Id. at 5a-6a, 115a-116a.

5. Ten years later, petitioner filed suit, alleging that respondents (who had purchased Cetus's PCR business) were marketing HIV detection kits that infringed its patents. Pet. App. 5a-6a, 31a. Respondents counterclaimed, 
contending, inter alia, that they possessed ownership interests in the patents because of Holodniy's agreement with Cetus. Id. at 7a, 122a-124a.

The district court rejected respondents' claim of ownership on several grounds. As relevant here, the court held that Holodniy's assignment to Cetus was ineffective to convey an interest in the patents because, under the Bayh-Dole Act, he lacked any such interest to convey. Pet. App. 61a. The court explained that when "the individual inventor is not a contracting party," "the Bayh-Dole Act provides that the individual inventor may obtain title only after the government and the contracting party have declined to do so." Ibid. (citing 35 U.S.C. 202(d)). Because "Stanford exercised its right and obtained title in the patents" under the BayhDole Act, the court concluded, Holodniy "had no interest to assign to Cetus." Id. at 62a.

In a later proceeding, however, the district court held that the patents were invalid for obviousness. See Board of Trs. of Leland Stanford Jr. Univ. v. Roche Molecular Sys., Inc., 563 F. Supp. 2 d 1016, 1040-1049 (N.D. Cal. 2008). Petitioner appealed that decision, and respondents crossappealed on the ownership issue. Pet. App. 2a-3a.

6. The court of appeals affirmed in part, vacated in part, and remanded. Pet. App. 1a-28a. As relevant here, the court held that petitioner had obtained no ownership interests in the patents from Holodniy because Holodniy had assigned his patent rights to Cetus, leaving nothing for him to assign to Stanford. Id. at 27a. The court explained that the agreement between Holodniy and Stanford, in which Holodniy "agree[d] to assign or confirm in writing" any invention he conceived or reduced to practice while at Stanford, was merely a promise to assign his rights "to Stanford at an undetermined time." Id. at 13a. By contrast, the court viewed Holodniy's agreement with 
Cetus - in which Holodniy stated that he "will assign and do[es] hereby assign to CETUS" his interest in inventions conceived as a consequence of his access to Cetus facilities and information —as "effect[ing] a present assignment" to Cetus of his future inventions. Id. at 14a (emphasis added). The court concluded that "Cetus's legal title vested first" and that Holodniy therefore had no rights to assign to Stanford with respect to the pertinent inventions. Ibid.

The court of appeals rejected petitioner's contention that the Bayh-Dole Act gave Stanford title to the patents. Pet. App. 18a-21a. In the court's view, the Bayh-Dole Act was relevant only to determine what residual rights Stanford and the government might have after effectuating the assignments in the Holodniy-Stanford and Holodniy-Cetus agreements. Id. at 19a-20a. The court stated that "Stanford was entitled to claim whatever rights were still available after the Government declined to exercise its option, including the rights of [Holodniy's co-authors on the patents]," but that Holodniy had already assigned his rights to Cetus. Id. at 19a. The court explained that Holodniy "still possessed rights at the time he signed the [agreement] with Cetus" and that the Act did not "automatically void the patent rights that Cetus received from Holodniy." Id. at 19a, 21a.

The court of appeals concluded that petitioner lacked standing to pursue the infringement claim because it had not acquired Holodniy's interest in the patents and, under Federal Circuit precedent, all co-owners must join as plaintiffs in an infringement suit. Pet. App. 27a. Based on its determination that petitioner lacked standing to pursue the claim, the court vacated the district court's judgment that the patents were invalid. $I d$. at 27a-28a. 
7. Petitioner filed a petition for rehearing and rehearing en banc, which the court of appeals denied. Pet. App. 75a-77a.

\section{DISCUSSION}

The court of appeals erred in holding that an individual inventor may contract around the Bayh-Dole Act's framework for allocating ownership of federally funded inventions. Under the Act, title to a subject invention vests in the contractor (i.e., the research institution), and the contractor may "elect to retain [that] title." 35 U.S.C. 202(a). An individual inventor can obtain title in a federally funded invention only if the contractor declines to take title (or fails to assert its statutory rights as required by the Act) and the government affirmatively authorizes the retention of title by the inventor. 35 U.S.C. 202(d). Here, Holodniy had no patent rights to assign to Cetus because title to the inventions initially vested in Stanford and Stanford exercised its Bayh-Dole Act rights. The court of appeals' decisionwhich holds that Holodniy's assignment to Cetus limited the patent rights that Stanford could assert under the Bayh-Dole Act—turns the Act's framework on its head.

The question presented is important. The Bayh-Dole Act reflects Congress's considered judgment about the best way to ensure that federally funded inventions are made available to the public and to encourage further science and technology research and development in the United States. The court of appeals' decision ignores that judgment and allows the wishes of a single inventor to override the Act's allocation of rights in federally funded inventions. The funds at issue are substantial: the federal government spends billions of dollars per year on science and technology research at United States colleges and universities, small businesses, and nonprofit organizations. 
This case is a suitable vehicle for resolving the question presented. The question presented is a pure matter of law, and the decision below has created immediate and substantial uncertainty about title to federally funded inventions. This Court's review of this important question is therefore warranted.

A. The Court Of Appeals Misconstrued The Bayh-Dole Act's Comprehensive Framework For Disposition Of Rights In Federally Funded Inventions

The Bayh-Dole Act replaced a welter of agency-specific statutes and funding agreements with a unified statutory framework for allocating rights in federally funded inventions. The court of appeals' decision upsets the balance struck by Congress and allows individual inventors to control the disposition of rights in federally funded inventions.

1. With respect to federally funded inventions, the Act establishes a statutory hierarchy of rights among the government, contractors, and inventors. The Act grants priority of title to the contractor by giving the contractor the statutory right to "elect to retain title" in the invention. 35 U.S.C. 202(a). Through this provision, the Act "establishes a presumption that ownership of all patent rights in government funded research will vest in [the] contractor," House Report 5, unless the contractor declines to retain title or fails to assert its rights. Under the Bayh-Dole Act, the contractor's ability to assert its statutory prerogatives does not depend on an assignment of rights by the individual inventor.

In certain circumstances, such as when the research to be performed under a particular funding agreement implicates especially sensitive government interests, the government may provide in the agreement that title to any resulting inventions will vest in the government. 35 U.S.C. 
202(a). The government also has specific statutory rights relating to the invention, such as licensing and march-in rights. 35 U.S.C. 202(c)(4), 203. But the contractor's decision to retain title controls unless the government has retained title through a funding agreement or the contractor fails to exercise its rights in the manner and within the time specified in the Act. 35 U.S.C. 202(a) and (c)(1)-(3).

The inventor may exercise rights in the invention only in limited circumstances-namely, when the contractor declines to retain title (or fails to exercise its rights under the Act) and the government funding agency decides, after consultation with the contractor, to grant the inventor's request for rights. 35 U.S.C. $202(\mathrm{~d})$. Thus, the inventor occupies the lowest position in the Bayh-Dole Act's hierarchy of rights in federally funded inventions, subordinate both to the contractor and the federal government. See, e.g., Platzer v. Sloan-Kettering Inst. for Cancer Research, 787 F. Supp. 360, 364-365 (S.D.N.Y. 1992) (concluding that "the intended beneficiaries of the Bayh-Dole Act are the [research] institutions themselves and the government," not the inventors).

The Bayh-Dole Act permitted Holodniy to assign to Cetus the same rights Holodniy himself would otherwise have possessed. With respect to any patentable invention that Holodniy might ultimately conceive or reduce to practice with the assistance of federal funds, however, Holodniy possessed only a contingent interest in obtaining title to the invention if the contractor waived or failed to exercise its rights under the Act and the government then authorized Holodniy to retain title. As events transpired, Stanford elected to retain title and complied with the statutory requirements for doing so, Pet. App. 5a-6a, so that contingent 
interest was of no practical value. ${ }^{1}$ And while nothing in the Bayh-Dole Act precluded Holodniy from assigning his own contingent interest to Cetus, Holodniy could not assign to Cetus any higher priority in the federally funded inventions than Holodniy himself would have possessed.

The court of appeals framed the question presented as whether Stanford's “election of title under Bayh-Dole had the power to void any prior, otherwise valid assignment of patent rights." Pet. App. 19a. Stanford's entitlement to retain title to the patented inventions, however, does not depend on the view that the Bayh-Dole Act "void[ed]" Holodniy's assignment of rights to Cetus. Holodniy assigned to Cetus his own "right, title, and interest in" any inventions conceived or reduced to practice "as a consequence of [his] access to CETUS' facilities or information," $i d$. at 123a; but the parties to that agreement surely understood that the scope of Holodniy's rights in any later-developed inventions would be determined under applicable law. If Holodniy's eventual contributions to the research that produced the patented inventions had been too insignificant to justify treating him as a co-inventor, for example, Cetus would have acquired no rights in those inventions because Holodniy would have had no such rights to assign. Similarly here, the Bayh-Dole Act did not "void" Holodniy's assignment to Cetus of all his rights in the relevant inventions; it simply limited, to the contingent interests de-

\footnotetext{
1 Under 35 U.S.C. 202(c)(7)(B), a nonprofit organization that retains title to a federally funded invention under the Bayh-Dole Act must share any royalties with the inventor. To the extent that Holodniy would otherwise be entitled to a share of royalties pursuant to that provision, that right would potentially be assignable to Cetus. Neither the parties nor the courts below have suggested, however, that any such royalties are in dispute.
} 
scribed above, the rights that Holodniy could potentially assign.

2. The court of appeals' decision turns the Bayh-Dole Act's hierarchy on its head. In the court's view, title to a federally funded invention belongs in the first instance not to the university, but to the inventor. The court stated that Holodniy "still possessed rights [in the invention] at the time he signed the [agreement] with Cetus," Pet. App. 19a, and it determined that Stanford's and the government's rights were subordinate to Holodniy's assignments, $i d$. at 13a-18a. The court considered the government's rights second, stating that "when the Bayh-Dole Act's provisions are violated, "the government can choose to take action $* * *$ [but] title remains with the named inventors or their assignees." IId. at 18a-19a (quoting Central Admixture Pharmacy Servs., Inc. v. Advanced Cardiac Solutions, P.C., 482 F.3d 1347, 1352-1353 (Fed. Cir.), cert. denied, 552 U.S. 1038 (2007)). The court put the contractor's rights last, stating that Stanford could only "claim whatever rights were still available after the Government declined to exercise its option." Ibid.

As a result, the court determined that an inventor like Holodniy may preclude a contractor from obtaining its statutory ownership interests in a federally funded invention simply by making a present assignment of rights to a third party. See Pet. App. 19a. Thus, under the decision below, which entity retains rights to a federally funded invention depends on the fortuity of whether the inventor assigned his rights, and whether that assignment came before the contractor's election of title-contrary to the uniform scheme for the allocation of patent rights in federally funded inventions that the Bayh-Dole Act was intended to establish. 
3. The court of appeals' decision also ignores the BayhDole Act's statement that "[t]his chapter [i.e., 35 U.S.C. 200 et seq.] shall take precedence over any other Act which would require a disposition of rights in subject inventions * * * in a manner that is inconsistent with this chapter." 35 U.S.C. 210(a). Under the Patent Act (as under the common law), the right to patent an invention generally belongs to the inventor, who may assign that right. See 35 U.S.C. 101, 115, 116, 261; see also Pet. App. 19a-20a. By its plain terms, however, the Bayh-Dole Act "take[s] precedence over" that allocation, 35 U.S.C. 210 (a), with respect to the federally funded inventions to which it applies. Thus, even assuming that Holodniy's assignment of Patent Act rights to Cetus would otherwise prevail over his assignment to Stanford, the priority rules set forth in the Bayh-Dole Act are controlling here.

\section{B. The Question Presented Is Important And Warrants This Court's Review}

The decision below raises an important question about the scope of a federal statute that applies to thousands of colleges and universities, small businesses, and nonprofit organizations across the United States and implicates billions of dollars per year in federal funding from a variety of government agencies.

1. Congress enacted the Bayh-Dole Act to replace a patchwork of varied statutory and agency approaches to ownership of federally funded inventions with a uniform and effective framework. House Report 3 (explaining that universities and small businesses were unable to "cope with the bewildering regulatory and bureaucratic problems associated with" the prior regime). Through the Act, Congress "establishe[d] a presumption that ownership of all patent rights in government funded research will vest in 
any contractor who is a non-profit research institution or a small business." Id. at 5 . Since 1980, contractors have generally understood that they may obtain good title to federally funded inventions, subject to certain rights retained by the government, by complying with the Act's requirements. See The Bayh-Dole Act-The Next 25 Years: Hearing Before the Subcomm. on Technology and Innovation of the $H$. Comm. on Science and Technology, 110th Cong. 1st Sess. 4-5 (2007); AAU Amicus Br. 2-3.

The court of appeals' decision upsets those settled expectations. Under the decision below, even when a contractor elects to retain title and complies with the requirements of the Act, an inventor may defeat that title by making an assignment to a third party, the terms or even existence of which may be unknown to the contractor at the time of the election and for years thereafter. Further, the question of which entity ultimately takes title may depend on variations in assignment language or the timing of inconsistent assignments. See WARF Amicus Br. 11. The decision below creates serious uncertainty about contractors' title to patents, raising the cost of due diligence for contractors and potential licensees, and making it difficult and risky for contractors to give potential licensees or investors warranties of good title to patents obtained through the Bayh-Dole Act framework.

2. The decision below also frustrates Congress's efforts to foster scientific research and development in the United States and to use federally funded inventions to benefit American workers. Congress required that non-profit contractors use "the balance of any royalties or income earned * * * for the support of scientific research or education," 35 U.S.C. 202(c)(7)(C), and ensure that any assignee granted the "exclusive right to use or sell any subject invention" agrees to manufacture any products using the subject 
invention "substantially in the United States" unless the government waives that condition, 35 U.S.C. 204. Under the decision below, an inventor may assign rights in a federally funded invention to a third party outside of the Act, thereby sidestepping those requirements.

The court of appeals' decision also calls into question the government's ability to manage federally funded inventions for the benefit of the public. The Act provides that, if a contractor does not take sufficient action to achieve practical application of the invention, is not adequately satisfying a public health or safety need related to the invention, or has not ensured that assignees with exclusive rights manufacture products using the invention substantially in the United States, the agency may "march in" and require the contractor to grant licenses to third parties. 35 U.S.C. 203. Those rights are a valuable tool to ensure that federal funding for research ultimately promotes the public interest, because they help provide "leverage to promote commercialization of federally funded inventions." GAO Report 912. Those rights would be jeopardized by the inventor's ability to assign rights in the invention outside of the Act's framework.

3. The amount of federal funding at issue is substantial. The federal government funds over half of all scientific and technical research conducted at colleges and universities in the United States. GAO Report 1; NSF, NSF 10-311, Academic R\&D Expenditures: FY 2008, at 8 \& tbl. 1 (2010) (NSF Report). In 2008, that amounted to more than $\$ 31$ billion in federal funds. NSF Report $8 \&$ tbl. 1; see Donna Fossum et al., Innovation in Academe: Federal $R \& D$ Funding and the Patenting Activities of U.S. Universities and Colleges 5-8 tbl. 2.1 (2009) (RAND Report) (listing federal research and development funding for top 100 colleges and universities). And that figure does not account for the 
billions of dollars of federal funds provided each year to small businesses and nonprofit organizations. That funding is crucial to scientific and technological innovation, as the amount of federal research funds an institution receives strongly correlates with the number of patented inventions it generates. RAND Report 19; AAU Amicus Br. 18-20; MIT Amicus Br. 7-8. The decision below allows individual inventors to allocate the benefits of federally funded research to third parties through individual contract assignments, rather than to contractors and to the public, as Congress intended. The "enormous" sum of federal funds at issue here is another "strong factor" counseling in favor of certiorari. Fidelity Fed. Bank \& Trust v. Kehoe, 547 U.S. 1051, 1051 (2006) (Scalia, J., joined by Alito, J., concurring in the denial of certiorari); see Eugene Gressman et al., Supreme Court Practice 269 (9th ed. 2007).

\section{This Case Is An Appropriate Vehicle For Resolving The Question Presented}

1. The court of appeals definitively resolved a pure question of law. Its resolution of this question was not dependent on the particular facts of this case. The court held that patent rights to a federally funded invention vest initially in the inventor, not the contractor, and that the inventor's transfer of rights to a third party effectively negates the contractor's otherwise timely election of rights under the Bayh-Dole Act. Pet. App. 18a-21a. That holding casts serious doubt on the ownership of a very substantial number of federally funded inventions. Certiorari is warranted on that basis. See, e.g., Festo Corp. v. Shoketsu Kinzoku Kogyo Kabushiki Co., 535 U.S. 722,739 (2002).

The Court should not await further consideration of the issue in the lower courts. Although questions regarding an individual's or a company's interest in a federally funded 
invention could conceivably arise in any type of property dispute, such issues typically have arisen in suits involving patent validity and infringement claims or contract claims against the United States, matters within the exclusive jurisdiction of the Federal Circuit. See, e.g., Central Admixture, 482 F.3d at 1349-1352; Campbell Plastics Eng'g \& Mfg., Inc. v. Brownlee, 389 F.3d 1243, 1244-1246 (Fed. Cir. 2004); see also 28 U.S.C. 1295. And because the Federal Circuit declined to rehear this case en banc, further percolation of the issue in that court is unlikely.

2. Contrary to respondents' suggestion (Br. in Opp. 15), contractors and the government cannot terminate the damage the Court below did to the Bayh-Dole Act scheme by modifying their assignment clauses in future contracts. Changing future contracts will not change the allocation of rights for the massive number of past and present agreements relating to ongoing or completed research over the three decades since the Act took effect. See Pet. 17-18. And even with respect to future contracts between universities and individual researchers, it is far from clear that a university can adequately protect its Bayh-Dole Act prerogatives simply by insisting on a present assignment of rights from the researcher. The university would still run the risk, for example, that the researcher had already assigned his rights to a third party, and that the earlier-intime assignment would be found controlling.

Respondents' other arguments against certiorari are unpersuasive. Although respondents suggest (Br. in Opp. 20-21) that the invention at issue was not conceived or reduced to practice with federal funds, the court of appeals appeared to decide the case on the assumption that it was, see Pet. App. 5a, and this Court should do the same, see, e.g., Hudson v. Michigan, 547 U.S. 586, 590 (2006). Respondents also contend (Br. in Opp. 17) that the question 
presented may not be outcome-determinative here, since respondents might ultimately prevail on alternative grounds (e.g., that the relevant patents are invalid) even if the court of appeals' Bayh-Dole Act ruling is reversed. But the court decided an important statutory question in a manner that upset decades of settled expectations, and the issue is sufficiently important to warrant this Court's review now.

Respondents also note (Br. in Opp. 11) that petitioner has not been deprived of all rights in the inventions because it obtained valid assignments from Holodniy's co-inventors. But petitioner's retention of rights in the patents through Holodniy's co-inventors is a fortuity; the court of appeals did not premise its analysis on that fact or condition its legal holding upon it. Respondents similarly contend ( $i d$. at 13) that this case is not important because it presents no issue of government patent rights. That likewise depends on the fortuity that Stanford was able to obtain rights through Holodniy's co-inventors and grant the government a license to practice the invention based on those rights. Because the court of appeals' flawed construction of the Bayh-Dole Act will be binding precedent in the Federal Circuit even in cases where the sole inventor of a federally funded invention assigns his rights to a third party, the presence of ameliorating circumstances in this particular case does not meaningfully reduce the practical impact of the decision.

3. Finally, respondents note (Br. in Opp. 14) the court of appeals' suggestion (Pet. App. 20a n.1) that the government may have "some other legal recourse" against an inventor who assigns to a third party all rights in a federally funded invention. But as respondents recognize (Br. in Opp. 2), the Federal Circuit's decision depends on the view that "the Bayh-Dole Act nowhere alters an inventor's basic freedom to assign his own rights in an invention to a third 
party." By upending the Bayh-Dole Act's hierarchy of rights, the court of appeals necessarily made the government's rights, like the contractor's rights, depend on the actions of an individual inventor. This Court should grant review now to correct the court of appeals' serious misunderstanding of the Bayh-Dole Act's framework for determining ownership of federally funded inventions.

\title{
CONCLUSION
}

The petition for a writ of certiorari should be granted.

Respectfully submitted.

\author{
NEAL KUMAR KATYAL \\ Acting Solicitor General \\ TONY WEST \\ Assistant Attorney General \\ MALCOLM L. STEWART \\ Deputy Solicitor General \\ BETH S. BRINKMANN \\ Deputy Assistant Attorney \\ General \\ Nicole A. SAHARSKY \\ Assistant to the Solicitor \\ General \\ SCOTT R. MCInTOSH \\ Teal Luthy Miller \\ Attorneys
}

SEPTEMBER 2010 